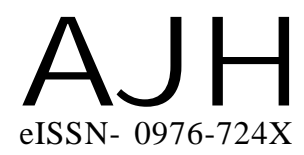

Article history :

Received : 23.01.2016

Accepted : 24.05.2016
THEASIAN JOURNALOF HORTICULTURE

Volume 11 | Issue 1 | June, 2016 | 208-217

Visit us -www.researchjournal.co.in

\title{
A review on organic farming in vegetable sector
}

\section{JUNAIF NAZIR, S.H. KHAN ${ }^{1}$, KOUSER PARVEEN ${ }^{1}$, B. AFROZA ${ }^{1}$ AND ALIMA SHABIR ${ }^{1}$}

ABSTRACT : Growing awareness of health and environmental issues associated with the intensive use of chemical inputs has led to interest in alternate forms of agriculture in the world. Organic agriculture is one among the broad spectrum production methods that are supportive of the environment. At present 35million hectares of agricultural land are managed organically by almost 1.4 million producers all over the world. In India, total area under organic management is 4.48 million hectare, out of this, cultivated area is 1.08 million hectare and remaining 3.4 million hectare is wild forest harvest collection area. The various components of organic farming are: Organic materials such as FYM, composts, green manures etc. for enrichment of soil fertility, biofertilizers for economizing nitrogen and phosphorus fertilizers, biopesticides, bioagents for controlling diseases, pests etc, high yielding varieties and hybrids resistant to biotic and abiotic conditions, crop rotation, intercropping, mulching etc. Organic farming reduces the need of purchased inputs, prevents environmental degradation, improves soil physical, chemical and biological properties, helps to sustain production and better yields, properly utilizes organic wastes, avoids pesticide residues in food and results in better quality product . Use of FYM, biofertilizers and vermicompost has resulted in maximum fruit yield in vegetables like tomato, brinjal and better nutritional qualities like increased ascorbic acid content in okra (Thakur et al., 2010 and Reddy, 2008). Use of biopesticides like spinosad helps in controlling diamond back moth in cabbage, biocontrol agents like trichogramma spp. reduces infestation of helicoverpa armigera in tomato, while use of mulches help in reducing weed infestation, disease incidence and improve overall yield of vegetable crops. In India, organic farming, in spite of the reduction in crop productivity by 9.2 per cent, provided higher net profit to farmers by 22.0 per cent compared to conventional farming. This was mainly due to the availability of premium price $(20-40 \%)$ for the certified organic produce and reduction in the cost of cultivation by 11.7 per cent.

KEY WORDS : Organic agriculture, Components, Vegetable crops

HOW TO CITE THIS ARTICLE : Nazir, Junaif, Khan, S.H., Parveen, Kouser, Afroza, B. and Shabir, Alima (2016). A review on organic farming in vegetable sector. Asian J. Hort., 11(1) : 208-217, DOI : 10.15740/HAS/TAJH/11.1/208-217. 